\title{
1. Law and Democracy: Contemporary Questions
}

\author{
Glenn Patmore ${ }^{1}$ and Kim Rubenstein ${ }^{2}$
}

Constitutional democracy is a contested concept. Caselaw since the early 1990s has recognised implied principles of representative and responsible government that go well beyond the mere text of the Australian Constitution, providing for a 'direct choice' of representatives by 'the people', and for electoral democracy. ${ }^{3}$ These judicial implications remain contentious to the present day. Moreover, the constitutional conventions that provide accountability for responsible government are evolving and subject to challenge. In addition, law's regulation of political and popular culture is becoming increasingly important due to changing social circumstances and technological developments. These changes create challenges, which this book responds to by asking a number of fundamental questions:

- How should the meaning of 'the people' in the Australian Constitution be defined by the High Court of Australia?

- How do developing judicial conceptions of democracy define citizenship?

- What is the legal right to participate in the political community?

- Should political advisors to Ministers be subject to legal accountability mechanisms?

- What challenges do applied law schemes pose to notions of responsible government and how can they be best addressed?

- How can the study of the ritual of electoral politics in Australia and other common law countries supplement the standard account?

- How might the ritual of the pledge of Australian citizenship limit or enhance democratic participation?

- What is the conflict between legal restrictions of freedom of expression and democracy, and the role of social media?

\footnotetext{
1 g.patmore@unimelb.edu.au; Glenn Patmore wishes to thank for their assistance, Mr Tom Appleby, Ms Candice Parr and Ms Anna Seddon who read material to him and provided research assistance. Their work was much appreciated. Special thanks must also be given to the Melbourne Law Research Service.

2 kim.rubenstein@anu.edu.au.

3 Australian Constitution s 7: 'The Senate shall be composed of senators for each State, directly chosen by the people of the State, voting, until the Parliament otherwise provides, as one electorate'; s 24: 'The House of Representatives shall be composed of members directly chosen by the people of the Commonwealth, and the number of such members shall be, as nearly as practicable, twice the number of the senators.'
} 
Examining the regulation of democracy this book brings together emerging and established scholars and practitioners with expertise in public law. It enriches public law scholarship, deepening and challenging the current conceptions of law's regulation of popular participation and legal representation. This volume is divided into three parts to identify the complexity and nuance of law and democracy in its contemporary doctrinal, conventional and socio-legal context.

These are:

- Assumptions and scope of constitutional democracy;

- The frontiers of accountability and responsible government; and

- Democracy, law and culture.

The purpose of the book is threefold. First, it raises and addresses a number of novel questions regarding law's regulation of democracy. Second, it aims to deepen our understanding of doctrinal scholarship by exploring its assumptions and its scope. Third, the book goes beyond doctrinal scholarship to consider important socio-legal questions about law's regulation of politics and culture. By considering a diverse range of topics pertaining to law's engagement with democracy in Australia and elsewhere, we believe the contemporary function of law will be better understood in its constitutional, political and cultural contexts.

\section{Assumptions and scope of constitutional democracy}

The modern conception of democracy is representative. ${ }^{4}$ The Australian Constitution establishes representative government by requiring that senators and members be 'directly chosen by the people'.${ }^{5}$ In other words, the Parliament is regarded as representative since the citizens directly choose members of Parliament in regular elections. ${ }^{6}$ However, very little about the electoral system is spelt out in the Australian Constitution. ${ }^{7}$ The design and function of the electoral system was left to Parliament and the political process. ${ }^{8}$ Moreover,

\footnotetext{
4 See Nicholas Aroney, "Towards the "best explanation" of the Constitution: Text, Structure, History and Principle in Roach v Electoral Commissioner' (2011) 30(1) University of Queensland Law Journal 145. Anne Twomey, 'Rowe v Electoral Commissioner: Evolution or Creationism?' (2012) 31(2) University of Queensland Law Journal, 181-202; Jennifer Clarke, Patrick Keyzer and James Stellios, Australian Constitutional Law Materials and Commentary (Lexisnexis, 9th ed, 2013) 1210-16.

5 See Stephen J in Ex rel McKinlay $v$ The Commonwealth (1975) 135 CLR 1 [20].

6 Suri Ratnapala and Jonathan Crowe, Australian Constitutional Law: Foundations and Theory (Oxford University Press, 3rd ed, 2012) 33.

7 David Clark, David Bamford and Judith Bannister, Principles of Australian Public Law (LexisNexis, 3rd ed, 2010) 175; Cheryl Saunders, The Constitution of Australia: A Contextual Analysis (Hart Publishing, 2011) 110. 8 ibid.
} 
key democratic concepts are not defined in the Australian Constitution, such as 'the people', 'citizenship' and 'political participation'. While the representative principle remains strong, there are uncertainties that exist, due to the sparse provisions for the establishment of democracy in the Australian Constitution. ${ }^{9}$ This uncertainty is reflected in High Court jurisprudence.

Elisa Arcioni addresses the meaning of the term 'the people' in the Constitution, highlighting the High Court's murky and complex treatment of the term. She considers cases on the meaning of the terms 'representative government' and 'alien', focusing respectively on who is included in, and who is excluded from the term 'the people'. The High Court has resolved the tensions in these definitional issues by identifying 'the people' through legislative developments, which has constitutionalised that membership. Arcioni concludes that whether we prefer deferral to the parliamentary choices over time recognised in legislative developments, as a new form of constitutional construction, or the judicial application of standards seen in other legal sources, depends not on an absolute rule regarding constitutional interpretation but rather on classic differences of viewpoint regarding the role of judicial review.

Kim Rubenstein and Niamh Lenagh-Maguire explain that there is no expressly defined concept of citizenship in the Australian Constitution. Citizenship is defined by Commonwealth legislation and in its relationship with the concept of representative government. After explaining the significance of citizenship in Australia's democratic structure, they examine the important case of Re MIMIA; ex parte Ame, which tied citizenship to voting rights, a 'thin' conception of citizenship. They argue for the adoption of a 'thicker' or broader conception of citizenship focusing on rights, political participation and identity. This offers the potential for a deeper understanding of citizenship to inform judicial development and popular views.

Glenn Patmore examines the right to participate in democratic decision making. The modern conception of democracy recognises a right of citizens to elect representatives to make legislative and executive decisions on their behalf. While this is a relatively limited conception of participation, his chapter illustrates how it can usefully define the scope and structure of contemporary constitutional democracy. He examines how this right to participate in collective decisions is authorised in the Constitution, legislation, and constitutional conventions. Patmore also enlarges upon the more limited understanding of the constitutional protection of the right to vote or to participate in the political life of the community referred to by members of the High Court in recent decisions. Like others, Patmore argues that the constitutional protection of the right to vote

9 Suri Ratnapala and Jonathan Crowe, Australian Constitutional Law: Foundations and Theory (Oxford University Press, 3rd ed, 2012). 
may act to entrench democratic rights like the secret ballot that have hitherto only been recognised in legislation. He also posits that there is a permeability between the norms of the Constitution and legislation in order to help better understand the nature and scope of this right. Thus, he conceives the right to participate to include the making of legislative and executive decisions, not just voting in elections.

\section{Accountability and responsible government}

The grand difficulty in politics is how to make the few accountable to the many. In Australia, formal accountability is provided through the principle of representative and responsible government. Representative democracy means that representatives are accountable to electors and responsible government means that Ministers must be members of Parliament, and accountable to it. Responsible government has been described as a chain of command or responsibility. According to the 'chain' metaphor, the Queen and GovernorGeneral are accountable to Ministers, who are accountable to the Parliament, which is in turn accountable to the people. Thus, officials are either responsible for or subject to the control of others. Only a few of the essential links in this chain are expressly recognised in the Constitution, for instance the requirement that Ministers must be members of Parliament and heads of government departments. Other conditions are to be found in the constitutional conventions of responsible government. According to constitutional convention, public servants are accountable to Ministers, who are accountable to the Parliament.

Two chapters address contemporary challenges to effective accountability provided by the system of responsible government. Yee-Fui $\mathrm{Ng}$ examines the responsibility of ministerial advisers. According to the principle of responsible government, Ministers receive advice from ministerial advisers, and are answerable for the implementation of that advice. Unlike public servants, ministerial advisors are not subject to public accountability mechanisms. However, Yee-Fui Ng argues that ministerial advisers are increasingly exercising executive power beyond what is allowed in the Statement of Standards for Ministerial Staff, and should therefore be subject to legal accountability mechanisms. These include appearing before parliamentary committees, as part of the concept of responsible government and judicial review under section 75(v) of the Constitution. She concludes that such measures would generate a more nuanced and multi-faceted notion of accountability. While Yee-Fui $\mathrm{Ng}$ examines the accountability of ministerial advisers, Joe Edwards examines accountability under intergovernmental agreements and their effects on the efficacy of responsible government. Edwards explains that applied law schemes are intergovernmental agreements, in which the various interested jurisdictions 
- either the Commonwealth and the States and Territories, or just the States and Territories - agree that a particular area requires regulatory uniformity through the adoption of a model law. These schemes can be administered by the Commonwealth, by States, by both, or by an independent authority. Edwards asks whether applied law schemes might undermine the accountability provided by responsible government. This doctrine assumes the voters have sufficient information to hold the government to account through elections at the ballot box. Given the complexity of applied law schemes, it appears that the chains of accountability become blurred and difficult to ascertain for citizens and legal advisors. Edwards concludes that while applied law schemes challenge traditional conceptions of accountability, ultimately they should be retained given they are capable of balancing the aim of regulatory uniformity with the requirement of responsible government.

\section{Democracy, law and culture}

The laws and institutions we adopt necessarily shape political participation. According to participatory theorists of democracy, citizens, through participation in democratic practices and institutions, can develop a 'publicspirited type of character' or may become a 'community-minded individual'. This is regarded as the 'educative effect' of democracy, which occurs through participation, not necessarily formal education. While this might be regarded as an idealised version of democracy, it challenges us to consider how participation in democratic institutions can promote self-development. Enhancing selfdevelopment provides an important rationale for contemporary representative democracy. Laws may provide opportunities for enhanced development such as through participation in voting, jury service and in small-scale organisations such as workplaces and community organisations.

The function of political participation and law is analysed by three contributors, taking us beyond the traditional educative function of democracy, with its focus on participation in political decision-making. These chapters examine popular forms of civic participation and democratic culture and its impact on the individual.

Two contributors address the role of ritual in politics that are authorised by the law. Graeme Orr examines the ritual dimensions of electoral law, explaining that the way the law structures an election creates a shared experience, patterned by norms. Political participation in Election Day creates a communal event a ritual of diverse shared experiences: for some, a chore, a public duty or a confessional moment. However, as Orr explains, 'the ritual is primarily built up in the patterned behaviour - what transpires in the internal reflections of 
different individuals is another matter'. One important pattern is based around the legal obligation to vote, which occurs on the one day that our secular society congregates to renew the mandate of representatives. Appreciating this enables us to better understand the social power of Australian electoral law. Orr also compares the ritual element of electoral law in Australia with the United States and the United Kingdom.

Anne Macduff examines the ritual of the citizenship pledge, and explains how it gives meaning to the state's conception of the ideal citizen. The pledge states:

From this time forward [under God]

I pledge my loyalty to Australia and its people

Whose democratic rights and liberties I respect, and

Whose laws I will uphold and obey.

While the citizenship applicant has the choice not to affirm with the words 'under God', they must make the pledge publicly at a citizenship ceremony. Macduff is critical of the public performance of the pledge and its content. She makes two key criticisms:

- The ritual situates the Australian ideal citizen as being obedient, compliant and law-abiding; and

- Although the pledge includes words such as 'democratic beliefs', 'rights' and 'freedoms, these words of the pledge do not clearly convey the active agency of Australian citizenship.

By active citizenship, she means 'more than political participation within the existing framework of laws and institutions, and includes critical protests that question the founding framework'. However, she notes that once a migrant becomes a citizen, 'they are legally free to engage in Australian democracy as they choose and to benefit from the democratic freedoms that other Australian citizens have'. Interestingly, while these rights and freedoms are referred to in the words of the pledge, she sees the ritual of the pledge as potentially adversely influencing future citizens' active engagement in democratic politics. She argues that the submission to legal authority embodied in the ritual of the pledge has the capacity to 'influence the behavior of candidates after they become citizens'.

Stephen Tully examines the political participation of citizens in democratic culture through social media. While Orr adopts a socio-legal approach, and Macduff adopts a critical legal studies perspective, Tully's analysis is grounded in respect of liberal rights. First, he considers how social media may enhance and limit democratic participation. Not only does he consider its opportunities and limits but, like Orr and Macduff, his work highlights the importance of 
the experience of democratic participation, in this case through social media. Tully provides examples of its use in countries like Egypt and Tunisia, where he examines social media's ability to shape democratic culture. Secondly, he highlights how legal restrictions can curtail democratic opportunities. While democratic states acknowledge the importance of freedom of expression through social media, they have justified some limits to protect national security and law enforcement. While some limits are legitimate, others are not. Tully argues that, '[s]tated at its highest, the use by governments of blocking or filtering technology violates the obligation of States to guarantee freedom of expression'. The freedom to participate through social media is also threatened in non-democratic countries. This includes by removing internet-content and by sometimes banning social media altogether. Tully's analysis highlights the tension between the new opportunities provided by social media for democratic participation, and resistance by the state through law. Social media can be perceived as a threat to the safety and stability of the state or, more contentiously, when it challenges the socio-political status quo.

\section{Conclusion}

While constitutional democracy has existed for over a century in Australia, key concepts in the field continue to be contested and developed. Some of these concepts have not been questioned and examined in sufficient detail. The contributions in this volume identify the value of rethinking the assumptions and scope of this field. Some contributors argue that the current constitutional assumptions need to be broadened in light of contemporary theories of democracy. Others propose reforms to accountability mechanisms for responsible government. Some others contend that the discipline needs to respond to new cultural and social realities. Thus, this book does not aim to provide a single answer; after all the law of democracy is multi-faceted and complex. Rather, this book offers a rich selection of new ways of thinking and provides us with new approaches to interpreting existing laws as well as understanding law in its broader social context. 
This text taken from Law and Democracy: Contemporary questions, edited by Glenn Patmore and Kim Rubenstein, published 2014 by ANU Press, The Australian National University, Canberra, Australia. 